\title{
Perancangan Sistem Deteksi Isyarat BISINDO Dengan Metode Adaptive Neuro-Fuzzy Inference System (ANFIS)
}

\author{
Nadia Intan Pratiwi ${ }^{1}$, Ida Widaningrum ${ }^{2}$, Dyah Mustikasari ${ }^{3}$ \\ ${ }^{1,2,3}$ Univesitas Muhammadiyah Ponorogo, Indonesia \\ Email : iwidaningrum.as@ gmail.com
}

\begin{abstract}
Abstrak
Tunarungu merupakan suatu kondisi dimana pendengaran seorang individu tidak dapat berfungsi secara normal. Maka, dibuatlah bahasa isyarat yang digunakan sebagai solusi terhadap permasalahan tersebut. Di Indonesia, bahasa isyarat yang di kenal adalah SIBI (Sistem Isyarat Bahasa Indonesia) dan BISINDO (Bahasa Isyarat Indonesia). Meskipun SIBI sudah diakui oleh pemerintah Indonesia, namun dalam penggunaanya kurang diminati. Penelitan ini dilakukan untuk mengenali isyarat tangan kosong. Dimana hal itu akan membantu pengguna secara alami tanpa adanya bantuan tambahan. Percobaan yang dilakukan menggunakan dataset yang diperagakan oleh 1 peraga. Pada prosesnya, karakteristik dari tangan diambil dengan menggunakan metode Histogram Oriented Gradient (HOG). Sedangkan untuk memisahkannya dari gambar latar belakang, digunakan segmentasi warna. Hasil dari proses tersebut kemudian diambil untuk melakukan klasifikasi. Adapun proses klasifikasinya menggunakan metode Adaptive Neuro-Fuzzy Inference System. Hasil dari pengujian yang dilakukan menghasilkan akurasi sebanyak 78,31\%. Permasalahan yang dilakukan.
\end{abstract}

Kata kunci: ANFIS, Bahasa Isyarat, Pengenalan Isyarat

\begin{abstract}
Deafness is a condition where an individual's hearing cannot function normally. So, sign language was created which was used as a solution to the problem. In Indonesia, the sign languages that are known are SIBI (Indonesian Sign Language System) and BISINDO (Indonesian Sign Language). Although SIBI has been recognized by the Indonesian government, in its use it is less desirable. This research was conducted to identify empty hand signals. Where it will help the user naturally without additional assistance. Experiments carried out using a dataset that was demonstrated by 1 display. In the process, the characteristics of the hand are taken using the Histogram Oriented Gradient (HOG) method. Whereas to separate it from the background image, color segmentation is used. The results of the process are then taken to classify. The classification process uses the Adaptive Neuro-Fuzzy Inference System method. The results of the tests carried out resulted in an accuracy of $78.31 \%$. The problem is done.
\end{abstract}

Keywords: ANFIS, Sign Language, Signal Recognition 


\section{Pendahuluan}

Di Indonesia, dikenal dua macam bahasa isyarat. Kedua bahasa isyarat tersebut adalah Sistem Isyarat Bahasa Indonesia (SIBI) dan Bahasa Isyarat Indonesia (BISINDO). Penggunaan BISINDO lebih didukung dibandingkan dengan SIBI. Seorang responden pada penelitan tersebut menyebutkan, bahwa isyarat pada SIBI lebih sulit dan panjang. Hal tersebut terbukti dengan adanya isyarat untuk imbuhan semisal ber, me, pe, an, nya, ke, dan di [1].

Penelitian di bidang bahasa isyarat dapat dikategorikan menjadi dua; yang berbasis penglihatan komputer (Computer Vision), sementara yang lain didasarkan pada data sensor [2], [3]. Sebuah kamera digunakan sebagai masukan pada pendekatan berbasis penglihatan komputer. Video diambil dalam bentuk file video yang disimpan sebelum diproses menggunakan pemrosesan gambar [4]-[6].

Sebuah gambar dapat dikenali di mesin dengan melibatkan penangkapan gambar dan pengenalan pola. Penangkapan sebuah isyarat dapat diperoleh dari pendekata Data Glove, ekstraksi fitur berbasis penglihatan komputer, maupun melalui Microsoft Kinect Xbox 360TM. Sedangkan pada lingkup pengenalan isyarat, teradapat beberapa metode yang digunakan untuk melakukannya. Sebagai contoh Hidden Markov Model (HMM), Artificial Neural Network (ANN) [7], dan Dynamic Time Warping (DTW). Permasalahan utama tentang sistem penerjemahan bahasa isyarat adalah akurasi dan efisiensinya. Dengan begitu, pemilihan metode penangkapan gambar serta metode klasifikasinya sangat berpengaruh. Karena itu, sebagai solusinya digunakan hybrid fuzzy dan Neural Network dengan isyarat yang ditangkap berbasis kamera Kinect [8].

Dalam penelitian ini dibuat untuk melakukan pengenalan isyarat dari Bahasa isyarat Indonesia (BISINDO). Adapun untuk melakukan pengenalan polanya dilakukan dengan metode Adaptive Neuro-Fuzzy Inference System (ANFIS). Sedangkan untuk penangkapan isyaratnya divariasikan dengan menggunakan kamera webcam. diminta untuk membaca petunjuk dengan hati-hati. Penulis bertanggung jawab untuk semua materi yang disajikan di makalah.

\section{Tinjauan Literatur}

Bahasa isyarat ialah bahasa komunikasi yang tidak menggunakan suara atau non-verbal communication. Bahasa ini mengutamakan cara manual, seperti gerakan tangan, bahasa tubuh dan gerak bibir, untuk berkomunikasi. Biasanya bahasa ini digunakan oleh orang yang bermasalah dalam pendengarannya [9] [10]. Bahasa isyarat tidak digunakan secara internasional, sehingga terdapat banyak sekali macamnya di setiap negara.

\subsection{Bahasa Isyarat Indonesia (BISINDO)}

BISINDO adalah bahasa isyarat penyesuaian dari Bahasa Isyarat Amerika yang bervariasi di setiap wilayah. Pada dasarnya, BISINDO adalah bahasa isyarat alami dari budaya asli Indonesia yang dapat dengan mudah digunakan dalam interaksi antar individu. Ini tentu membuatnya berbeda dari SIBI, di mana bahasa isyarat adalah bahasa yang dibuat oleh individu normal. 
Pengenalan dan pengembangan BISINDO tidak dapat dipisahkan dari campur tangan organisasi Gerakan untuk Kesejahteraan bagi Penyimpangan Indonesia, disingkat GERKATIN. Gerakan ini adalah satu-satunya organisasi penyandang cacat tuli di Indonesia, yang semuanya dikelola oleh orang-orang cacat tunarungu.

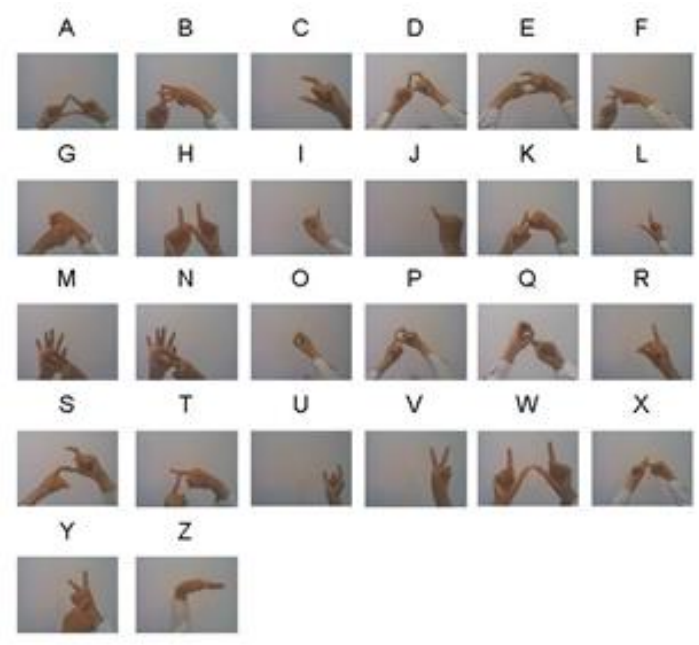

Gambar 1: Dataset yang digunakan untuk penelitian.

Guna mengenali isyarat dari gambar ke teks, maka diperlukan dataset untuk mengatasinya. Isyarat yang digunakan merupakan isyarat alfabet dari BISINDO. Pengambilan dataset dilakukan dengan cara mengambil video saat isyarat oleh satu orang peraga. Adapun kondisi pencahayaan dilakukan dengan cahaya yang tidak terlalu gelap maupun terlalu terang (lihat gambar 1). Selain itu, latar belakang yang digunakan merupakan dinding dengan warna putih polos.

Guna menunjang pengambilan data tersebut, maka digunakan usb webcam Logitech C170. Resolusi diatur kedalam ukuran 1024×768 piksel dengan ruang warna RGB. Gambar yang diambil berupa isyarat satu tangan maupun dua tangan. Adapun untuk isyarat dengan gerakan, pengambilan datanya dilakukan dengan memperagakan gerakan dari awal hingga akhir. Namun hanya gerakan yang tidak mirip dengan gerakan lainnya lah yang diambil. Sehingga pada pengumpulan data, didapatkan 100 sampel isyarat di setiap hurufnya untuk digunakan sebagai data latih. Sedangkan untuk data uji, diambil 50 sampel di setiap hurufnya. Sedangkan pengambilan isyarat yang bergerak, dilakukan dengan mengambil gambar pergerakan seperti gambar 2 . Adapun pengambilan gambarnya dilakukan tanpa mengambil gambar yang sama seperti isyarat yang lain agar mempermudah pengenalan.
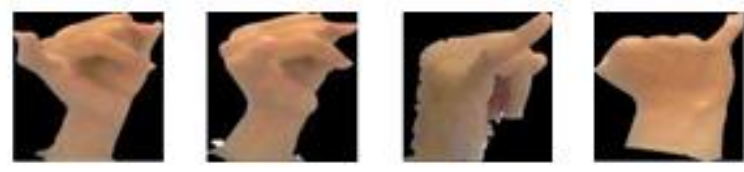

Gambar 2: Pengambilan gambar untuk isyarat J. 


\subsection{Adaptive Neuro Fuzzy System}

Adaptive Neuro Fuzzy Inference System (ANFIS) adalah sejenis jaringan saraf yang didasarkan pada sistem inferensi fuzzy Takagi-Sugeno [11]. Pada prinsipnya, ANFIS adalah kombinasi dari prinsip-prinsip logika fuzzy dan jaringan saraf. ANFIS menggunakan sistem inferensi fuzzy dengan kemampuan untuk belajar dan beradaptasi [12].

Penerapan metode ANFIS membutuhkan sepasang data input / output untuk digunakan sebagai data pelatihan. Dimana ini membuat jaringan adaptif ANFIS seperti jaringan saraf. Pelatihan ANFIS mematuhi aturan IF-THEN.

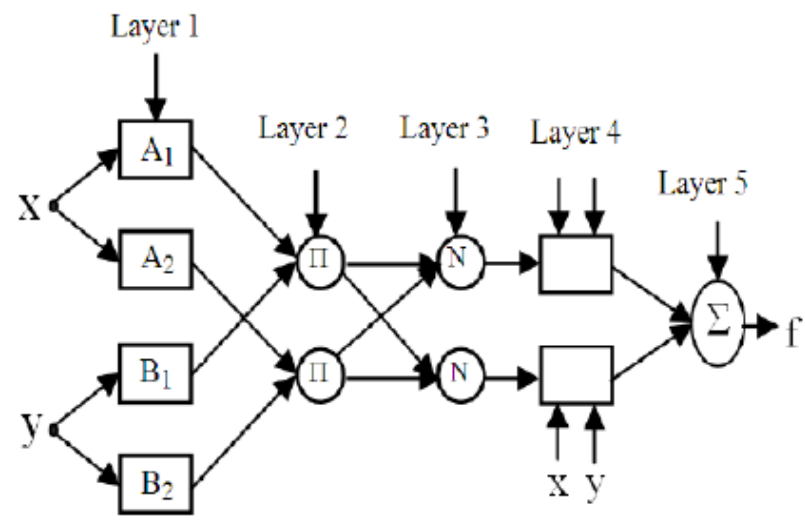

Gambar 3: Arsitektur Anfis untuk 2 inputan, 2 aturan Sugeno FIS [11],[12], [13]

\section{Metodologi}

Penelitian yang dilakukan berbasis pada ekstraksi fitur pada tangan yang di klasifikasikan dengan ANFIS. Pengenalan isyarat dari gambar dalam penelitian ini dilakukan dengan 3 tahapan. Tahapan tersebut adalah tahap pra-pengolahan, tahap ekstraksi fitur, dan tahap klasifikasi. Langkah-langkah yang digunakan pada ketiga tahapan tersebut dijelaskan sebagai berikut.

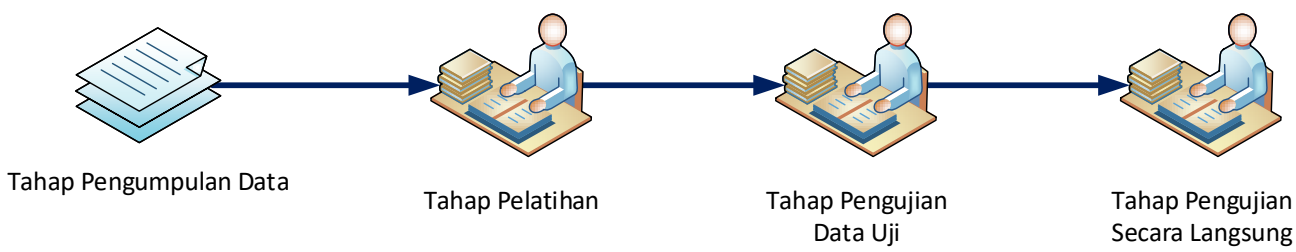

Gambar 4: Alur Penelitian. 
Tahapan penelitian yang dilakukan terdiri dari tahap pengumpulan data, tahap pelatihan, tahap pengujian dengan data uji, dan tahap pengujian secara langsung (lihat gambar 4):

a. Tahap Pengumpulan Data; dilakukan untuk mengumpulkan dataset untuk tahap pelatihan dan pengujian dengan data uji. Tahapan ini diawali dengan mengumpulkan video untuk dijadikan dataset. Video diambil dari webcam Logitech C170 dengan resolusi $1024 \times 768$ piksel (ruang warna RGB).

b. Tahap Pelatihan; Tahap pelatihan merupakan tahapan untuk membentuk struktur ANFIS. Pembentukan tersebut didapatkan dari data latih sebagai datasetnya. Adapun jumlah sampel yang digunakan sebanyak 100 sampel di setiap hurufnya. Sehingga terkumpul 2600 sampel pada keseluruhan data latih.

c. Tahap Pengujian Secara Langsung; Tahap pengujian secara langsung dilakukan dengan menggunakan kamera Logitech C170, resolusi yang digunakan sebesar 1024×768 dengan struktur warna RGB. Peragaan dilakukan oleh 1 peraga dengan memperagakan gerakan sebanyak 5 kali, area yang diperagakan berupa area tangan saja.

\section{Hasil dan Diskusi}

\subsection{Tahap Pra-pengolahan}

Tahap pra-pengolahan dilakukan untuk memfokuskan pada area tangan saja. Untuk melakukannya, maka gambar diolah menggunakan teknik segmentasi warna. Pada penelitian dilakukan segmentasi warna dengan ruang warna $\mathrm{YCbCr}$. Hasilnya adalah jika area yang dianggap tangan, maka area tersebut berwarna putih. Sedangkan untuk area di sekitarnya, berwarna hitam. Gambar yang didapatkan, kemudian diolah untuk dikurangi titik-titik yang menganggu di dalamnya. Kemudian area gambar diperkecil hingga pada area yang diduga sebagai tangan (lihat gambar 5). Adapun gambar yang diperkecil merupakan gambar yang telah dikembalikan warna aslinya. Lalu dari gambar tersebut diubah ruang warnanya ke grayscale. Selain itu gambar diubah ukurannya menjadi 90×90 piksel.

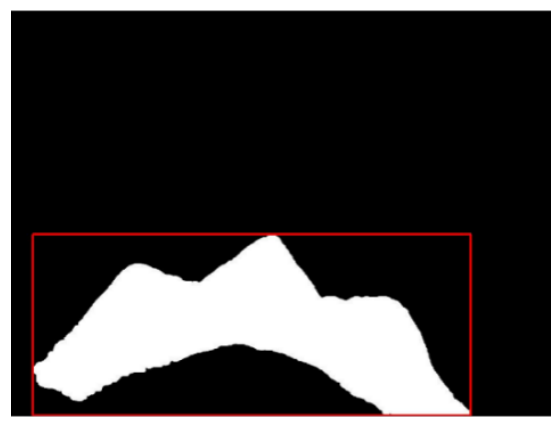

Gambar 5: Gambar biner hasil seleksi warna yang diperkecil ke area tangan saja.

\subsection{Tahap Ekstraksi Fitur}

Pada tahapan ini, gambar diambil karakteristiknya untuk dijadikan data masukan pada tahap klasifikasi. Pertimbangan yang dilakukan ketika membuat satu set fitur, harus memenuhi beberapa pertimbangan seperti berikut [14]:

- Gambar untuk objek dari kelas yang sama pasti sangat fitur serupa. 
- Fitur untuk objek dari kelas yang berbeda harus terasa berbeda.

- Fitur harus skala, terjemahan, dan rotasi invarian, yang berarti bahwa mereka harus dapat mengenali objek terlepas dari ukuran, lokasi, dan orientasi mereka.

Histogram Oriented Gradient (HOG) merupakan deskripsi fitur yang digunakan dalam penglihatan komputer dan pengolahan citra untuk tujuan deteksi objek [15]. Gambar dari tahap pra-pengolahan dibagi menjadi $3 \times 3$ blok, sehingga hasilnya dapat dilihat pada Error! Reference source not found.

Komputasi gradien kemudian dilakukan untuk menemukan histogramnya. Hasil dari langkah tersebut, kemudian data di normalisasikan. Hasil normalisasi tersebut lah yang merukapan hasil dari deskripsi HOG. Pada penelitian ini, hasilnya berupa data dengan ukuran 1×108 piksel.

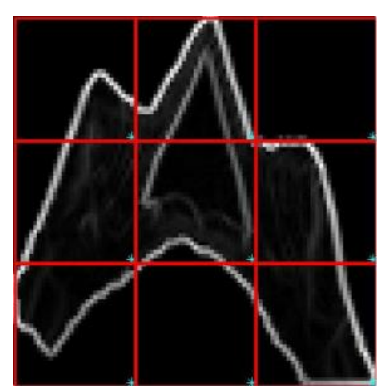

Gambar 6: Pembagian blok pada gambar magnitude.

\subsection{Tahap Klasifikasi}

Proses pengenalan isyaratnya dilakukan untuk melakukan dua tahap, yaitu pelatihan dan pengujian. Proses pengenalannya diperlihatkan pada gambar 7.

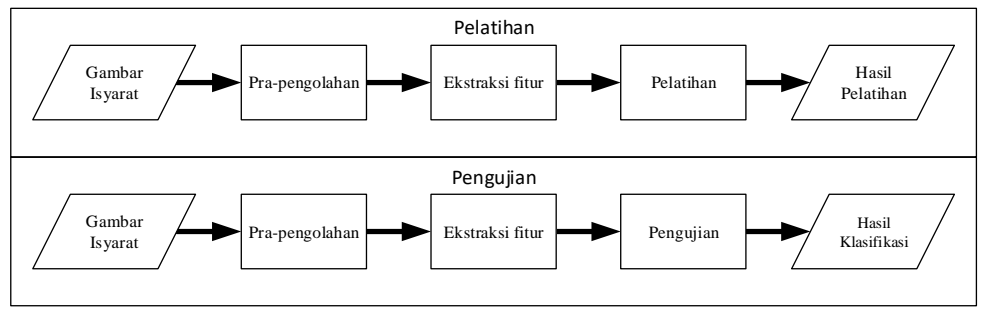

Gambar 7: Proses pengenalan isyarat.

Tahapan ini mengekstrak karakteristik dari tahapanan sebelumnya untuk dikelompokan dalam aturan IF-THEN. Metode pembelajaran ANFIS sendiri menggunakan model Sugeno, sehingga dapat diketahui aturannya adalah [16]:

Jikax adalah Ai dany adalah Bi, makafi $i=p_{i} x+q_{i} y+r_{i}$

Berdasarkan diagram pada gambar 3, maka urutan perhitungannya adalah sebagai berikut; 
1) Layer 1 atau lapisan pertama. Ini adalah simpul yang dihasilkan dengan menggunakan persamaan 2. Label linguistik dinyatakan dengan $A_{i}(x)$ dan himpunan fuzzy pada $A\left(A_{1}\right.$, $\mathrm{A}_{2}, \mathrm{~B}_{1}$ dan $\mathrm{B}_{2}$ ) untuk $\quad O_{I}^{1}$. Kurva gauss (persamaan 3) digunakan untuk mencari parameter dari fungsi keanggotaan, disini digunakan $\gamma$ (nilai domain pusat kurva) dan $\mathrm{k}$ (lebar kurva)

$O_{I}^{1}=\mu A i(x) \cdots \cdots(2)$

$\mu A i(x)=\exp \left(-k(\gamma-x)^{2}\right) \cdots \cdots(3)$

2) Layer 2 atau lapisan kedua. Disini simpul yang ada merupakan simpul tetap. Semua sinyal yang datang merupakan outnya (persamaan 4 .

$w_{i}=\mu A i(x) \times \mu B i(y) \cdots \cdots(4)$

3) Layer 3 atau lapisan ketiga. Sama seperti layer 2, semua simpul merupakan simpul tetap. Disini dilakukan perhitungan rasio derajat keaktifan aturan ke-i pada lapisan sebelumnya [17]. Kemuadian hasilnya dinormalisasikan (persamaan (5))

$\bar{w}_{i}=w_{i} \times\left(w_{1}+w_{2}\right) \cdots \cdot(5)$

4) Layer Layer 4. Lapisan tiga merupakan simpul adaptif. Parameternya $\left\{\quad p_{i} x, q_{i} y, r_{i}\right\}$ (persamaan (6)) disebut parameter konsekuensi.

$$
O_{i}^{4}=\sum_{i} \bar{w}_{i} f_{i}=w_{i}\left(p_{i} x+q_{i} y+r_{i}\right) \cdots \cdot \cdot(6)
$$

5) Layer 5. Disini hanya ada lapisan tunggal $\Sigma$ yang merupakan simpul tetap [17], merupakan total keseluruhan sinyal yang datang (persamaan (7))

$$
O_{I}^{5}=f=\sum_{i} \bar{w}_{i} f_{i}=\left(w_{1} f_{1}+w_{2} f_{2}\right) /\left(w_{1}+w_{2}\right) \cdots \cdot(7)
$$

Pada pembuatan strukturnya, digunakan pula metode pengelompokan data. Adapun untuk mencapainya, maka digunakan Subtractive Clustering. Pengelompokan data yang digunakan, merupakan gabungan antara metode yang diteliti oleh Steve Chiu [18] dan Roger Jang [19] [20]. Adapun algoritma dari metode yang digunakan dijabarkan sebagai berikut.

1) Menentukan data yang akan di cluster: Data masukan dijadikan sebagai data yang diolah dalam cluster. Hasil dari proses cluster sendiri berupa pusat cluster dan sigma $(\sigma)$. Kedua data keluaran tersebutlah yang diproses sebagai tambahan data. Data keluaran tersebut berfungsi untuk membentuk struktur ANFIS.

2) Menetapkan nilai-nilai yang dibutuhkan pada metode subtractive clustering: Terdapat beberapa atribut yang ada untuk melakukan perhitungan dengan subtractive clustering. Atribut 
tersebut diantaranya adalah Squash Factor $(Q)$, Accept Ratio, dan Reject Ratio. Adapun kegunaan dari atribut tersebut adalah untuk menentukan pusat cluster. Dimana dalam perhitungannya, sebuah titik diterima sebagai pusat jika rasionya lebih besar dari Accept Ratio. Selain itu, bila rasio tidak lebih besar dari Accept Ratio, titik tersebut masih diterima jika nilai rasionya masih lebih besar dari Reject Ratio. Titik data tersebut baru dapat diterima jika jaraknya cukup jauh dari pusat cluster lain. Jarak tersebut didapatkan dari penjumlahan antara rasio dengan jarak terdekat titik data dengan suatu pusat cluster lainnya. Adapun pencarian pusat cluster terhenti apabila sudah tidak memenuhi persyaratan yang ada. Selain dari ketiga atribut tersebut, terdapat atribut lain yang dibutuhkan. Atribut tersebut adalah jari-jari $(r)$, nilai maksimal $\left(x \max _{j}\right)$, dan nilai minimal $\left(x \min _{j}\right)$. Nilai maksimal merupakan nilai terbesar dari data $x_{j}$. Begitu pula nilai minimal merupakan nilai terkecil dari data $x_{j}$.

3) Menormalisasikan data [21]: Normalisasi data dilakukan untuk menskalakan nilai pada rentang tertentu. Untuk menormalisasikannya, dapat digunakan persamaan 8. Normalisasi data xij dilakukan dengan mengurangi nilai xij dengan nilai minimal dari xj. Kemudian hasilnya dibagi oleh pengurangan antara nilai maksimal dan minimalnya.

$x_{i j}=\frac{\left(x_{i j}-x m i n_{j}\right)}{\left(x \max _{j}-x m i n_{j}\right)},(i=1,2, \ldots, m) \cdots .$.

4) Melakukan pehitungan untuk menemukan potensi awal dan menentukan pusat cluster: Potensi awal dihitung dengan persamaan 9 bila diketahui jumlah $m$ lebih dari 1 . Sedangkan untuk $\mathrm{m}$ sama dengan 1 , dihitung dengan persamaan seperti pada 10 . Sedangkan penunjang perhitungan tersebut diperlihatkan pada persamaan 11 dan 12 .

$$
\begin{aligned}
& P_{i}^{0}=\sum_{k=1}^{n} \exp \left(-4\left(\sum_{j=1}^{m} D_{i s t_{k 1}^{2}}\right)\right) \cdots \cdots \\
& P_{i}^{0}=\sum_{k=1}^{n} \exp \left(-4\left(\text { Dist }_{k 1}^{2}\right)\right) \cdots \cdot \cdot \\
& D_{i s t_{k j}}=\frac{\left(T_{j}-x_{k j}\right)}{r a} \cdots . .
\end{aligned}
$$

Proses yang dilakukan kemudian menghasilkan nilai dari potensi awal. Kemudian dari nilai tersebut diambil pusat cluster dengan mencari titik tertingginya. Adapun pusat cluster tersebut haruslah memenuhi kriteria pusat cluster. Iterasi kemudian dilanjutkan bila perhitungan yang dilakukan pada potensi awal, masih memenuhi kriteria untuk dijadikan pusat cluster.

5) Melakukan perhitungan untuk potensi lain dan menentukan pusat cluster:Perhitungan yang dilakukan pada potensi awal kemudian dilanjutkan untuk mencari potensi lain pada iterasi selanjutnya. Adapun perhitungan pada pencarian potensi lain bila nilai m lebih dari 1 ditunjunkan pada 13. Sedangkan untuk nilai $\mathrm{m}$ sama dengan 1 ditunjukan pada 14 . Untuk menunjang perhitungan tersebut, maka diperlukan pula perhitungan pada 15 dan 16.Kemudian potensi tersebut dicari pusat cluster. Penentuan pusat cluster diambil dari nilai tertinggi pada perhitungan yang dilakukan, serta harus memenuhi kriteria agar dapat ditentukan. Iterasi yang dilakukan tetap 
berlanjut sampai iterasi berhenti. Iterasi berhenti ketika sudah tidak ditemukan lagi pusat cluster yang memenuhi kriteria. Adapun nilai pada iterasi tidak boleh bernilai negatif. Untuk mengatasi nilai negatif pada iterasi yang ada, maka pada titik dengan nilai negatif dijadikan nilai 0 .

$$
\begin{aligned}
& P_{i}=\operatorname{Center}_{i}-\left(\max \left(P_{i}^{0}\right) \times\left(\exp \left(-4 \times \sum \operatorname{Dist}_{i}^{2}\right)\right)\right) \cdots \cdot \cdot \\
& P_{i}=\operatorname{Center}_{i}-\left(\max \left(P_{i}^{0}\right) \times\left(\exp \left(-4 \times \operatorname{Dist}_{i}^{2}\right)\right)\right) \cdots \cdots(14) \\
& Q a=\frac{1}{(Q \times r)} \cdots \cdots(15) \\
& \text { Dist }_{k i}=\left(\text { Center }_{i}-x_{i}\right) \times Q a \cdots \cdots
\end{aligned}
$$

Menentukan sigma dan pusat cluster:Pusat cluster diambil dari nilai normalisasi pada titik tertinggi potensi yang dilakukan. Sedangkan nilai sigma sendiri diambil dengan persamaan 17.

$\sigma_{j}=r_{j} \times\left(\frac{\left(\max x_{j}-\min x_{j}\right)}{\sqrt{8}}\right) \cdots \cdots(17$

Proses pengenalan pola dilakukan untuk melakukan dua tahapan. Tahap pertama adalah pelatihan, sedangkan yang kedua adalah pengujian. Baik pengujian maupun pelatihan dilakukan dengan menggunakan dataset yang dipersiapkan. Untuk tahap pelatihan, maka digunakan sampel sebanyak 100 gambar di setiap hurufnya. Sedangkan pada tahap pengujian digunakan 50 sampel saja.

Pelaksanaan uji coba pada tahap pelatihan dilakukan dengan mempersiapkan data terlebih dahulu. Kemudian gambar diolah pada tahap pra-pengolahan. Lalu masuk ke tahap ekstraksi fitur untuk didapatkan data masukan. Dengan bergitu, hasilnya mampu didapatkan. Adapun hasil akurasinya didapatkan dengan dilakukan perhitungan pada 8. Sedangkan waktu yang dilakukan pada tahap pelatihan dijalankan selama 4 jam 56 menit dan 40 detik (17800 detik). Sedangkan pada subtractive clustering yang diatur pada Squash Factor bernilai 2 dan Reject Ratio pada 0.28.

Sedangkan pada tahap pengujian dilakukan dengan mengambil data terlebih dahulu, kemudian gambar diproses dan menghasilkan grafik pada gambar 8. Pada hasil yang didapatkan, maka kesalahan yang mendeteksi kurang dari 10 terjadi pada huruf "N", "S", dan "B". Adapun kesalahan deteksi yang terjadi pada ketiga huruf tersebut diperlihatkan pada gambar 9. Dapat diketahui bahwa kesalahan terbesar pada pengujian huruf $\mathrm{N}$ terjadi karena terdeteksi pada $\mathrm{K}$ sebanyak 1 huruf, L sebanyak 1 huruf, dan pada M sebanyak 48. Sedangkan pada pengujian $\mathrm{S}$ kesalahan terjadi karena terdeteksi pada huruf I sebanyak 1, Q sebanyak 1 , R sebanyak $6, \mathrm{~T}$ sebanyak 4, U sebanyak 4, dan X sebanyak 3. Adapun sisa dari deteksi pada huruf S tidak dapat terdeteksi. Sedangkan deteksi pada huruf B kesalahan deteksi terjadi karena terdeteksi pada huruf E sebanyak $7, \mathrm{~F}$ sebanyak $13, \mathrm{G}$ sebanyak $11, \mathrm{H}$ sebanyak 1 , $\mathrm{K}$ sebanyak 3 , L sebanyak $1, \mathrm{M}$ sebanyak 3, N sebanyak 1, dan P sebanyak 1. Sedangkan akurasi pada pengujian didapatkan dengan menggunakan perhitungan 8. Hasilnya, dari keseluruhan data yang digunakan, menghasilkan akurasi sebanyak 78,31\% pada waktu yang kurang dari 1 detik. 


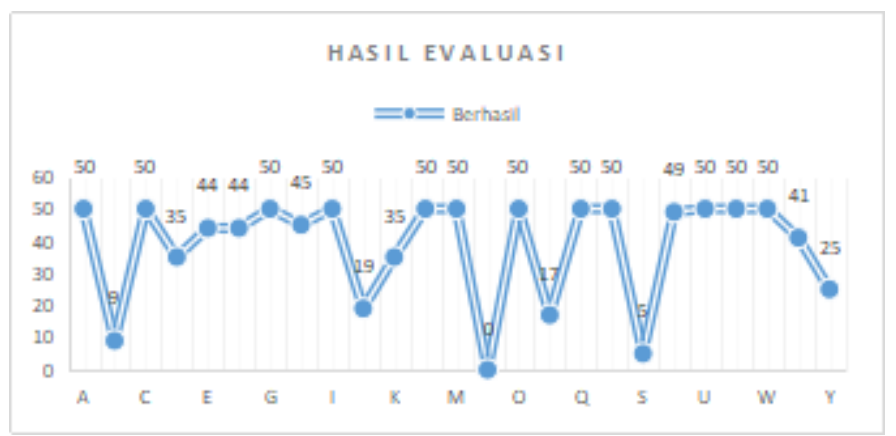

Gambar 8. Hasil pengujian dari data uji.

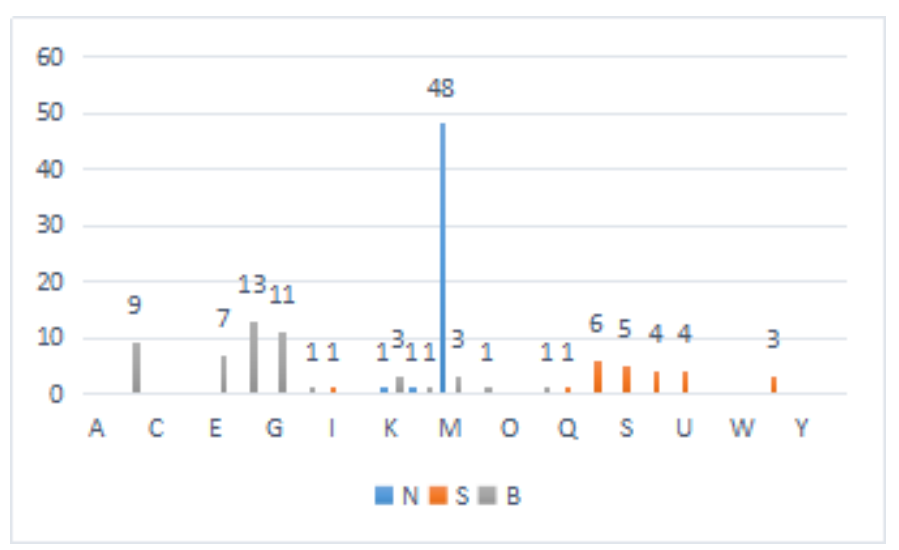

Gambar 9. Kesalahan deteksi.

\section{Kesimpulan}

Setelah tahapan-tahapan pada penelitian dilakukan, maka dapat diketahui bahwa hasil pelatihan mencapai akurasi pada 98,08\%. Adapun waktu yang dibutuhkan sangatlah lama, yakni 4 jam 56 menit dan 40 detik (17800 detik). Sedangkan untuk pengujian mencapai akurasi sebesar 78,31\% dengan waktu kurang dari 1 detik. Adapun kesalahan yang mendeteksi kurang dari 10 isyarat terjadi pada huruf "B", "N", dan "S". Pada huruf "B" kebanyakan terdeteksi sebagai " $F "$. Sedangkan pada huruf "N" terdeteksi pada huruf "M", sedangkan pada huruf "S" terjadi karena terdeteksi sebagai " $R$ ". Kesalahan-kesalahan tersebut dapat terjadi karena penggunaan parameter pada pelatihan kurang tepat.

\section{Referensi}

[1] R. A. Mursita, "Respon Tunarungu Terhadap Penggunaan Sistem Bahasa Isyarat Indonesa (Sibi) Dan Bahasa Isyarat Indonesia (Bisindo) Dalam Komunikasi,” INKLUSI, vol. 2, no. 2, pp. 221-232, 2015.

[2] J. Ma, W. Gao, J. Wu, and C. Wang, "A continuous Chinese sign language recognition system," Proc. Fourth IEEE Int. Conf. Autom. Face Gesture Recognit. (Cat. No. PR00580), pp. 428-433, 2000. 
[3] M. Maraqa and R. Abu-Zaiter, "Recognition of Arabic Sign Language (ArSL) using recurrent neural networks," 1st Int. Conf. Appl. Digit. Inf. Web Technol. ICADIWT 2008, vol. 2012, no. February, pp. 478-481, 2008.

[4] H. Brashear, T. Starner, P. Lukowicz, and H. Junker, "Using multiple sensors for mobile sign language recognition," Seventh IEEE Int. Symp. Wearable Comput. 2003. Proceedings., pp. 45-52, 2003.

[5] T. Hninn and H. Maung, "Real-Time Hand Tracking and Gesture Recognition System Using Neural Networks," World Acad. Sci. Eng. Technol., vol. 3, no. 2, pp. 466-470, 2009.

[6] E. Stergiopoulou and N. Papamarkos, "Hand Gesture Recognition Using a Neural Network Shape Fitting Technique," Eng. Appl. Artif. Intell., vol. 22, no. 8, pp. 1141-1158, 2009.

[7] D. Kaushik, "Hand Gesture Recognition on Indian Sign Language using Neural Network," vol. 6, no. 4, pp. 554-565, 2016.

[8] Sutarman, M. Abdul Majid, and J. Mohamad Zain, "A review on the development of Indonesian sign language recognition system,” J. Comput. Sci., vol. 9, no. 11, pp. 1496-1505, 2013.

[9] D. Ling and A. H. Ling, Aural habilitation: The foundations of verbal learning in hearing-impaired children. Alex Graham Bell Assn for Deaf, 1978.

[10] R. E. Clark and G. Salomon, "Why should we expect media to teach anyone anything?," in Learning from media: Arguments, analysis, and evidence, 2nd ed., 2012, pp. 37-71.

[11] L. R and K. Rajasekaran, "Sign Language Recognition Datasets," Int. J. Emerg. Technol. Comput. Sci. Electron., vol. 8, no. 1, pp. 123-125, 2014.

[12] K. Assaleh, "Extraction of fetal electrocardiogram using $\mathrm{H} \infty$ adaptive algorithms," IEEE Trans. Biomed. Eng., vol. 54, no. 1, pp. 59-68, 2007.

[13] A. A. Bazmi, M. Davoody, and G. Zahedi, "Electricity Demand Estimation Using an Adaptive Neuro-Fuzzy Network: A Case Study from the State of Johor, Malaysia," Int. J. Chem. Environ. Eng., vol. 3, no. 4, pp. 284-295, 2012.

[14] A. Khotanzad and J.-H. Lu, "Classification of invariant image representations using a neural network,” Acoust. Speech Signal Process. IEEE Trans., vol. 38, pp. 1028-1038, 1990.

[15] R. K. Shangeetha., V. Valliammai., and S. Padmavathi., "Computer vision based approach for Indian sign language character recognition," 2012 Int. Conf. Mach. Vis. Image Process. MVIP . IEEE, 2012, pp. 181-184, 2012.

[16] S. Dour, "Design of ANFIS System for Recognition of Single Hand and Two Hand Signs for Indian Sign Language," vol. 2013, no. Icwac, pp. 18-25, 2013.

[17] D. R. Anamisa, “Adaptive Neuro-Fuzzy Inference System (ANFIS).” 2018.

[18] S. L. Chiu, "Fuzzy Model Identification Based on Cluster Estimation,” J. Intell. Fuzzy Syst., vol. 2, no. 3, pp. 267-278, 1994.

[19] J.-S. R. Jang, C.-T. Sun, and E. Mizutani, "Neuro-fuzzy and soft computing-a computational approach to learning and machine intelligence," IEEE Trans. Automat. Contr., vol. 42, no. 10, pp. 1482-1484, 1997.

[20] Mathworks, Fuzzy Logic Toolbox ${ }^{T M}$ User's Guide. The MathWorks, Inc. The, 2016.

[21] N. Azizah, D. Yuniarti, and R. Goejantoro, "Penerapan Metode Fuzzy Subtractive Clustering (Studi 
Nadia Intan Pratiwi ${ }^{1}$, Ida Widaningrum ${ }^{2}$, Dyah Mustikasari ${ }^{3}$

Kasus: Pengelompokkan Kecamatan di Provinsi Kalimantan Timur Berdasarkan Luas Daerah dan Jumlah Penduduk Tahun 2015),”J. EKSPONENSIAL, vol. 9, no. 2, pp. 197-206, 2018. 